\title{
Physical computer games for motivating physical play among elderly
}

\author{
Jessen, Jari Due; Lund, Henrik Hautop ; Jessen, Carsten
}

Published in:

Gerontechnology

Publication date:

2014

Document Version

Publisher's PDF, also known as Version of record

Link back to DTU Orbit

Citation (APA):

Jessen, J. D., Lund, H. H., \& Jessen, C. (2014). Physical computer games for motivating physical play among elderly. Gerontechnology, 13(2), 220.

\section{General rights}

Copyright and moral rights for the publications made accessible in the public portal are retained by the authors and/or other copyright owners and it is a condition of accessing publications that users recognise and abide by the legal requirements associated with these rights.

- Users may download and print one copy of any publication from the public portal for the purpose of private study or research.

- You may not further distribute the material or use it for any profit-making activity or commercial gain

- You may freely distribute the URL identifying the publication in the public portal

If you believe that this document breaches copyright please contact us providing details, and we will remove access to the work immediately and investigate your claim. 
J.D. JESSEN, H.H. LUND, C. JESSEN. Physical computer games for motivating physical play among elderly. Gerontechnology 2014; 13(2):220; doi:10.4017/gt.2014.13.02.185.00 Purpose To avoid falls and stay healthy, it is important that elderly people preserve their muscle strength. Therefore, physical training for the elderly remains an ongoing area of research. Current training methods consist primarily of rehabilitative training and/or optional exercise classes with a physiotherapist or volunteers. This paper presents a new solution that motivates elderly people to engage in physical training by introducing simple, fun, and challenging physical computer games. Method In the project we use modular playware tiles (Figure 1) ${ }^{1}$. The tiles were used in two elder centers (16 participants, averaging 79 years old), a rehabilitation center (12 participants, averaging 79 years old) and a hospital (12 participants, averaging 85.33 years old). Each week, there was 1-2 training sessions, and care was taken to ensure that each participant received at least 12 minutes of training in each session. Observations and informal interviews where performed during the sessions. The data were categorized and analyzed using theoretical coding. Results \& Discussion The introduction of physical computer games on modular tiles for elderly participants was highly motivating and very successful, corresponding with results from other user groups (i.e. rehabilitation patients and children²). There was special interest in memory games that challenged the elderly both physical and mentally. The coaches asked for 2 minutes of training time for each game, but the elderly kept playing for up to 10-15 min of a single game. The games created a playful atmosphere, which improved motivation compared with standard rehabilitation training and exercise. Several participants complained they did not have enough time to play. There was a high degree of competition among the elderly players for most points, and against themselves to beat their own records, which indicates that games can improve exercise time and intensity. This was supported by participants' physical improvement; measurements at the elder centers showed improvements on Chair Stand 24\%, Timed Up and Go 21\%, 6 Minutes Walking Test 29\% (tests from senior fitness test ${ }^{3}$ ), Tandem Line Walk 66\%, for all $p<0.001$ ) and measured at the rehabilitation center where improvement on Dynamic Gait Index was $12.3 \%, p<0.05)^{4}$. Thus, play on modular tiles seems to create a strong motivation for participation in therapeutic activities, as well as measurable health improvements, among elderly users.

\section{References}

1. Lund HH. 2009 IEEE International Conference on Rehabilitation Robotics 2009;571-575; doi:10.1109/ICORR.2009.5209517

2. Lund $\mathrm{HH}$. Modular Interactive Tiles for Rehabilitation - Evidence and Effect. WSEAS international conference on education and educational technology; Selected topics in applied computer science; 2010:520-525

3. Rikli RE, Jones CJ. Medicine \& Science in Sports \& Exercise 1999;31:S399; doi:10.1097/00005768199905001-02042

4. Lund $\mathrm{HH}$, Jessen J. Effects on community-dwelling elderly playing with modular interactive tiles. International Conference on Serious Games and Edutainment; 2010

Keywords: work \& leisure, physical computer games, motivation, physical training, elder Address: Center for Playware, Technical University of Denmark, DK-2800 Lyngby, Denmark E: jdje@elektro.dtu.dk
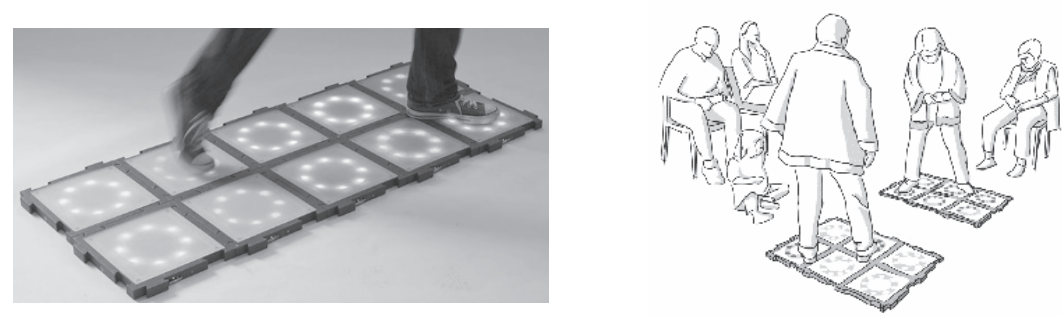

Figure 1. Modular Playware Tiles

Figure 2. Playware Tiles in use in an elder center 